\title{
Diacetyl levels and volatile profiles of commercial starter distillates and selected dairy foods
}

\author{
M. I. Rincon-Delgadillo, A. Lopez-Hernandez, I. Wijaya, and S. A. Rankin ${ }^{1}$ \\ Department of Food Science, University of Wisconsin-Madison, 1605 Linden Drive, Madison 53706
}

\begin{abstract}
Starter distillates (SDL) are used as ingredients in the formulation of many food products such as cottage cheese, margarine, vegetable oil spreads, processed cheese, and sour cream to increase the levels of naturally occurring buttery aroma associated with fermentation. This buttery aroma results, in part, from the presence of the vicinal dicarbonyl, diacetyl, which imparts a high level of buttery flavor notes and is a key component of SDL. Diacetyl (2,3-butanedione) is a volatile product of citrate metabolism produced by certain bacteria, including Lactococcus lactis ssp. diacetylactis and Leuconostoc citrovorum. In the United States, SDL are regarded as generally recognized as safe ingredients, whereby usage in food products is limited by good manufacturing practices. Recently, diacetyl has been implicated as a causative agent in certain lung ailments in plant workers; however, little is published about the volatile composition of SDL and the levels of diacetyl or other flavoring components in finished dairy products. The objective of this work was to characterize the volatile compounds of commercial SDL and to quantitate levels of diacetyl and other Flavor and Extract Manufacturers Association-designated highpriority flavoring components found in 18 SDL samples and 24 selected dairy products. Headspace volatiles were assessed using a solid-phase microextraction and analyzed by gas chromatography-mass spectrometry. In addition to diacetyl (ranging from 1.2 to $22,000 \mu \mathrm{g} / \mathrm{g}$ ), 40 compounds including 8 organic acids, 4 alcohols, 3 aldehydes, 7 esters, 3 furans, 10 ketones, 2 lactones, 2 sulfur-containing compounds, and 1 terpene were detected in the SDL. A total of 22 food samples were found to contain diacetyl ranging from 4.5 to $2,700 \mu \mathrm{g} / 100$ g. Other volatile compounds, including acetaldehyde, acetic acid, acetoin, benzaldehyde, butyric acid, formic acid, furfural, 2,3-heptanedione, 2,3-pentanedione, and propanoic acid, were also identified and quantified in SDL or food samples, or both. The results obtained in
\end{abstract}

Received August 12, 2011.

Accepted November 12, 2011.

${ }^{1}$ Corresponding author: sarankin@wisc.edu this work summarize the volatile composition of commercial SDL and the approximate levels of diacetyl and other Flavor and Extract Manufacturers Associationdesignated high-priority flavoring components found in SDL and selected dairy foods.

Key words: diacetyl, toxicity, starter distillate

\section{INTRODUCTION}

Starter distillate (SDL) is a generally recognized as safe (GRAS) food ingredient (CFR, 2011a) used to improve the aroma of many foods, such as sour cream, cottage cheese, baked goods, beverages, margarine, and vegetable oil spreads. Typically derived from the fermentation of a citrate-containing substrate, commercial SDL is available as a water- or oil-based liquid or as an encapsulated powder. Aside from the aqueous or lipid solvent, SDL contains high levels of the vicinal dicarbonyl, diacetyl, in addition to minor levels of other volatile compounds (CFR, 2011a). Diacetyl (2,3-butanedione) has long been recognized as imparting a distinctive buttery or butterscotch note in foods, such as cottage cheese (Hempenius et al., 1965; Antinone et al., 1994), beer (Portno, 1966; Landaud et al., 1998), and wine (Hayasaka and Bartowsky, 1999; Bartowsky and Henschke, 2004). The production of diacetyl occurs naturally as a function of specific pathways involving the intermediate $\alpha$-acetolactic acid (Veringa et al., 1984; Monnet et al., 1994) and as a product of valine synthesis in yeast (Chuang and Collins, 1968). As a means of intensifying and standardizing the buttery aroma beyond levels natively present, SDL are routinely incorporated into foods.

The US Code of Federal Regulations (CFR; Section 184.1848) defines SDL as a steam distillate obtained by fermentation of a medium containing skim milk fortified with citric acid at levels of $0.1 \%$. This medium is then fermented by specific lactic acid bacteria (LAB) including Streptococcus lactis, Streptococcus cremoris, Strep. lactis ssp. diacetylactis, Leuconostoc citrovorum, or Leuconostoc dextranicum. According to the same legislation, butter-like flavors present in the volatile fraction of SDL include diacetyl as the major flavor component with lesser amounts of acetaldehyde, ethyl 
formate, ethyl acetate, acetone, ethyl alcohol, 2-butanone, acetic acid, and acetoin. As potential respiratory hazards, each of these compounds is listed as either high priority (diacetyl, acetaldehyde, acetic acid, and acetoin) or low priority (ethyl formate, ethyl acetate, acetone, and 2-butanone) substances by the Flavor and Extract Manufacturers Association (FEMA, 2004).

Long-term exposure via inhalation to high levels of diacetyl vapors has been associated with the onset of the illness bronchiolitis obliterans, a debilitating lung disease (Ezrailson, 2002; Kreiss, 2007; van Rooy et al., 2007; Kanwal, 2008). Bronchiolitis obliterans is a rare, non-reversible disease wherein the formation of granular tissue obstructs the small airways (Chan and Allen, 2004), reducing lung capacity. Bronchiolitis obliterans has been linked to the inhalation of industrial volatiles, including ammonia, chlorine, hydrogen fluoride, sulfur dioxide, and diacetyl (Kullman et al., 2005). Due to the risk that diacetyl may pose, many flavoring companies have developed non-diacetyl-based flavorants comprising homologous carbonyls such as acetoin, 2,3-pentanedione, 2,3-hexanedione, 2,3-heptanedione, and diacetyl trimers (OSHA, 2010). Although alternative substances for diacetyl have GRAS status and are approved for use in food, recent reports have published potential health risks of these homologs as similar to diacetyl (Hubbs et al., 2010; NIOSH, 2010).

With either the conventional SDL or the non-diacetyl alternates, little is published detailing the volatile composition of SDL. To that end, this work seeks to provide information on the volatile profiles of commercially available SDL products and non-diacetyl-based flavorants, with a survey of diacetyl and related volatiles in selected dairy foods where such flavorants have been added.

\section{MATERIALS AND METHODS}

\section{Starter Distillates}

Samples of commercially available SDL- $(\mathrm{n}=11)$ and non-diacetyl- $(\mathrm{n}=7)$ based flavorants were obtained from different US manufacturers in liquid form (Table 1). These samples, labeled as natural or natural and artificial dairy flavors, are intended for several different food applications, including margarine and vegetable oil spreads, cottage cheese, sour cream, salad dressings, dairy analogs, sauces and gravies, snacks, soups, frosting mixes, and confectionary and bakery products as declared by the manufacturer. All samples were stored at $4^{\circ} \mathrm{C}$ until analysis, which occurred within the expiration dates.

\section{Selected Dairy Products}

Commercial US-made food samples (5 cottage cheeses and 19 margarines and vegetable oil spreads) labeled either natural or natural and artificial in the ingredient declarations were purchased at local markets (Table 2). All samples were stored under refrigeration temperatures $\left(4^{\circ} \mathrm{C}\right)$ until used for analysis, which occurred within the expiration dates.

\section{Standards}

Authentic compounds noted in Table 3 were purchased from a single manufacturer (Sigma-Aldrich Corp., St. Louis, MO), with the following exceptions: formic acid (Acros Organics, Pittsburgh, PA); lactic acid (Alfa Aesar, Ward Hill, MA); HPLC-grade water was obtained for dilution purposes (Fisher Scientific, Chicago, IL). Furfuryl alcohol (99\%) was used as an internal standard at a final concentration of $100 \mu \mathrm{g} / \mathrm{g}$ (Sigma-Aldrich Corp.).

\section{Volatiles Analysis}

Liquid SDL $(100 \mu \mathrm{L})$ were mixed with $1.9 \mathrm{~mL}$ of HPLC-grade water and placed in 8-mL glass vials capped with Teflon-lined septa. Commercial dairy products were prepared by mixing $1.0 \mathrm{~g}$ and placed in 8-mL glass vials capped with Teflon-lined septa.

The headspace volatiles were adsorbed at $40^{\circ} \mathrm{C}$ for 20 min with a 1-cm PDMS/Carboxen SPME fiber (Supelco Inc., Bellefonte, PA) for analysis by gas chromatography. Separation of volatile compounds was performed using a gas chromatograph (Agilent 6890N; Agilent Technologies Inc., Palo Alto, CA) fitted with a fused silica capillary column $(\mathrm{RTx}-5 \mathrm{MS}, 30-\mathrm{m}$ long $\times 0.25-\mathrm{mm}$ i.d. $\times 0.5-\mu \mathrm{m}$ film thickness; Restek Corp., Bellefonte, PA) and coupled to a mass selective detector (Agilent 5973 MS; Agilent Technologies Inc.). Helium was the carrier gas at a constant flow rate of $1.0 \mathrm{~mL} / \mathrm{min}$. The oven temperature was programmed from 40 to $220^{\circ} \mathrm{C}$ at a rate of $10^{\circ} \mathrm{C} / \mathrm{min}$, with an initial holding time of $5 \mathrm{~min}$. Electron impact ionization was used with a voltage of 70 eV. An $\mathrm{m} / z$ scan range of 29 to $350 \mathrm{amu}$ was collected at $4.44 \mathrm{scans} / \mathrm{s}$. Data analysis was performed using the accompanying computer software (ChemStation Software Rev. D.02.00 SP1; Agilent Technologies Inc.). The identification of all odorants reported in this study was made by matching the sample mass spectra with those from a published database (NIST version 1.7 mass spectral database; Agilent Technologies Inc.) and comparing retention times with those of authentic standards. 
Table 1. Descriptions, diacetyl concentrations, label information, and recommended uses of selected starter distillates (SDL), as provided by commercial manufacturers

\begin{tabular}{|c|c|c|c|c|}
\hline Sample & Description & $\begin{array}{l}\text { Diacetyl level }{ }^{1} \\
\quad(\mu \mathrm{g} / \mathrm{g})\end{array}$ & Label statement & Recommended use \\
\hline SDL1 & SDL buttermilk flavor & 27,000 & Natural flavor & Margarines, spreads, and salad dressings \\
\hline SDL2 & Natural creamy butter flavorant & $15,000-16,500$ & Natural flavor & Dairy products \\
\hline SDL3 & Concentrated SDL & $14,700-15,300$ & Natural flavor & $\begin{array}{l}\text { Cottage cheese, processed cheese, } \\
\text { margarine, baked goods }\end{array}$ \\
\hline SDL4 & Natural butter and culture acid flavorant & 15,000 & Natural and artificial flavor & Dairy and baked goods \\
\hline SDL5 & Natural SDL & 15,000 & Natural and artificial flavor & Dairy products \\
\hline SDL6 & Pale yellow liquid with flavor and aroma of concentrated butter & 15,000 & Natural flavor & Dairy products \\
\hline SDL7 & Kosher SDL & 15,000 & Natural flavor & Dairy products \\
\hline SDL8 & Custom-blend SDL buttermilk flavor & 5,300 & Natural flavor & Bakery and confectionery \\
\hline SDL9 & Natural butter flavor with lactic acid & 4,800 & Natural flavor & Butter \\
\hline SDL10 & Activator SDL buttermilk flavor & 4,800 & Natural and artificial flavor & Sour cream and cottage cheese \\
\hline SDL11 & Liquid SDL & 1,000 & Natural and artificial flavor & Dairy products \\
\hline SDL12 & Butter flavor & 0 & Natural and artificial flavor & Dairy and baked goods \\
\hline SDL13 & Natural butter flavor & 0 & Natural flavor & $\begin{array}{l}\text { Analog dairy products, margarine, } \\
\text { snacks, sauces, soups }\end{array}$ \\
\hline SDL14 & Butter-type flavor & 0 & Natural and artificial flavor & Analog dairy products, salad dressings \\
\hline SDL15 & Natural SDL-type flavor & 0 & Natural flavor & $\begin{array}{l}\text { Bakery, salad dressing, sauces, } \\
\text { gravies, soups, analogs }\end{array}$ \\
\hline SDL16 & Natural SDL flavor & 0 & Natural flavor & $\begin{array}{l}\text { Analogs (cheese and cream), margarine, } \\
\text { salad dressings, popcorn, sauces and } \\
\text { gravies (without cheese or dairy) }\end{array}$ \\
\hline SDL17 & Natural diacetyl type replacer & 0 & Natural flavor & Dairy products \\
\hline SDL18 & Diacetyl replacer & 0 & Natural and artificial flavor & Dairy products \\
\hline
\end{tabular}

${ }^{1}$ Concentration as declared by the manufacturers. 
Table 2. Commercial products evaluated in this study

\begin{tabular}{lll}
\hline Sample $^{1}$ & Product description & Flavor statement $^{2}$ \\
\hline CC1 & Cottage cheese, $4 \%$ fat minimum & Natural \\
CC2 & Cottage cheese, $4 \%$ fat minimum & Natural \\
CC3 & Cottage cheese, $2 \%$ fat & Natural \\
CC4 & Cottage cheese, 1\% fat & Natural \\
CC5 & Fat-free cottage cheese & Natural and artificial \\
SS1 & $56 \%$ Vegetable oil spread (spray form) & Natural and artificial \\
SS2 & $44 \%$ Vegetable oil spread (spray form) & Natural \\
MS1 & $80 \%$ Vegetable oil margarine & Natural and artificial \\
MS2 & $80 \%$ Vegetable oil margarine & Natural and artificial \\
MS3 & $79 \%$ Vegetable oil spread & Natural and artificial \\
MS4 & $70 \%$ Vegetable oil spread & Natural and artificial \\
MS5 & $65 \%$ Vegetable oil spread & Natural and artificial \\
MS6 & $65 \%$ Vegetable oil spread & Natural and artificial \\
MS7 & $65 \%$ Vegetable oil spread & Natural and artificial \\
MS8 & $60 \%$ Vegetable oil spread & Natural and artificial \\
MS9 & $60 \%$ Vegetable oil spread & Natural and artificial \\
MS10 & $53 \%$ Vegetable oil spread & Natural and artificial \\
MS11 & $53 \%$ Vegetable oil spread & Natural and artificial \\
MS12 & $52 \%$ Vegetable oil spread & Natural and artificial \\
MS13 & $48 \%$ Vegetable oil spread & Natural \\
MS14 & $39 \%$ Vegetable oil spread & Natural and artificial \\
MS15 & $37 \%$ Vegetable oil spread & Natural and artificial \\
MS16 & $35 \%$ Vegetable oil spread & Natural and artificial \\
MS17 & $50 / 50$ Butter spread blend & Natural \\
\hline${ }^{1}$ CC $=$ cottage cheese; SS = spread in spray form; MS = margarine or vegetable oil spread. \\
${ }^{2}$ As declared by the manufacturers. & \\
& &
\end{tabular}

The following compounds were selected for quantitation based on their presence in test samples and FEMAdesignated toxicity priority. Quantitative analysis was based on the linear response range of a 4-point series of external calibration curves for the following compounds (with their respective ranges): diacetyl (5-40,000 $\mu \mathrm{g} / \mathrm{g}$ ), acetaldehyde (1.0-100 $\mu \mathrm{g} / \mathrm{g})$, acetic acid (1,000-200,000 $\mu \mathrm{g} / \mathrm{g})$, acetoin $(10-100,000 \mu \mathrm{g} / \mathrm{g})$, benzaldehyde (0.5$50 \mu \mathrm{g} / \mathrm{g})$, butyric acid $(100-10,000 \mu \mathrm{g} / \mathrm{g})$, formic acid (5,000-50,000), furfural $(0.1-10 \mu \mathrm{g} / \mathrm{g}), 2,3$-heptanedione $(10-1,000 \mu \mathrm{g} / \mathrm{g}), 2,3$-pentanedione $(1.0-10,000$ $\mu \mathrm{g} / \mathrm{g})$, and propanoic acid $(500-10,000 \mu \mathrm{g} / \mathrm{g})$. All analysis were performed in triplicate $\left(R^{2}>0.99\right)$.

\section{RESULTS AND DISCUSSION}

The volatile constituents identified in SDL are reported in Table 3. A total of 40 compounds were positively identified and grouped in the in the following categories: acids, alcohols, aldehydes, esters, furans, ketones, lactones, sulfur-containing compounds, and terpenes.

Several organic acids were identified in the SDL samples (Table 3). Acetic acid was the most abundant and found in 15 samples, followed by propanoic acid found in 8 SDL samples. Butyric, hexanoic, and octanoic acids were detected in 6,5 , and 5 different SDL samples, respectively. Lactic acid and formic acid were found in 3 and pyruvic acid was found in 2 different SDL samples.

Some SDL manufacturers reported that organic acids were added to the SDL samples, including acetic acid (SDL4 and SDL10), lactic acid (SDL4 and SDL9), propanoic acid (SDL4, SDL8, and SDL10), butyric acid (SDL8 and SDL10), and hexanoic acid (SDL8 and SDL10). An unspecified mixture of medium-chain fatty acids and coconut oil were declared as ingredients in SDL13 and SDL14 samples. Medium-chain fatty acids such as hexanoic and octanoic acid were positively identified in both of these samples with a ratio of 1:1.5 in SDL13 and 1:1.2 in SDL14. Among the organic acids identified in this study, octanoic acid was exclusively detected in non-diacetyl-based flavorants, whereas formic acid, lactic acid, and pyruvic acid were detected solely in diacetyl-based flavorants.

A total of 4 alcohols were identified (Table 3). Ethanol and propylene glycol were found in 7 different samples; 1-propanol and 2,3-butanediol were detected in SDL4 and SDL9, respectively. Propylene glycol is widely used as a solvent in the production of dairy flavorants (Miedema and Schildknecht, 2007).

Among the 3 aldehydes identified (Table 3), acetaldehyde was the most abundant. Acetaldehyde was found in 6 , vanillin in 2 , and benzaldehyde in a single SDL sample. Acetaldehyde was identified in SDL2, SDL3, SDL13, SDL15, SDL17, and SDL18 flavorants in a range 


\begin{tabular}{|c|c|c|c|c|c|c|c|c|c|c|c|c|c|c|c|c|c|c|c|c|c|}
\hline \multirow[b]{2}{*}{ Compound } & \multirow[b]{2}{*}{ PEL data $^{1}$} & \multirow[b]{2}{*}{$\mathrm{LC}_{50}{ }^{2}$} & \multicolumn{19}{|c|}{ SDL sample } \\
\hline & & & 1 & 2 & 3 & 4 & 5 & 6 & 7 & 8 & & 9 & 10 & 11 & 12 & 13 & 14 & 15 & 16 & 17 & 18 \\
\hline \multicolumn{22}{|l|}{ Acid } \\
\hline Acetic acid & TWA $10 \mu \mathrm{g} / \mathrm{g}\left(25 \mathrm{mg} / \mathrm{m}^{3}\right)$ & $\begin{array}{l}\text { Inhalation in mouse } \\
5,620 \mu \mathrm{g} / \mathrm{g} \text { per } 1 \mathrm{~h}\end{array}$ & + & + & + & + & + & + & + & + & & + & + & + & + & & & + & & + & + \\
\hline Butyric acid & ND & ND & & & & & & & & + & & & + & & + & + & + & + & & & \\
\hline Formic acid & TWA $5 \mu \mathrm{g} / \mathrm{g}\left(9 \mathrm{mg} / \mathrm{m}^{3}\right)$ & $\begin{array}{l}\text { Inhalation in rat } 7.4 \\
\mathrm{mg} / \mathrm{L} \text { per } 4 \mathrm{~h}\end{array}$ & & + & & & + & & & & & + & & & & & & & & & \\
\hline Hexanoic acid & ND & $\begin{array}{l}\text { Inhalation in mouse } \\
4,100 \mathrm{mg} / \mathrm{m}^{3} \text { per } 2 \mathrm{~h}\end{array}$ & + & & & & & & & + & & & + & & & + & + & & & & \\
\hline Lactic acid & ND & ND & & & & + & + & & & & & + & & & & & & & & & \\
\hline Octanoic acid & ND & ND & & & & & & & & & & & & & + & + & + & & & + & + \\
\hline Propanoic acid & TWA $10 \mu \mathrm{g} / \mathrm{g}$ & $\begin{array}{l}\text { Inhalation in rat } 0.49 \\
\mathrm{mg} / \mathrm{L} \text { per } 4 \mathrm{~h}\end{array}$ & + & & & + & + & + & + & + & & & + & & & & & & & & + \\
\hline Pyruvic acid & ND & ND & & & & & + & & & & & + & & & & & & & & & \\
\hline 2,3-Butanediol & ND & $\mathrm{ND}$ & & & & & & & & & & + & & & & & & & & & \\
\hline Ethanol & $\begin{array}{l}\text { TWA } 1,000 \mu \mathrm{g} / \mathrm{g} \\
\left(1,900 \mathrm{mg} / \mathrm{m}^{3}\right)\end{array}$ & $\begin{array}{l}\text { Inhalation in } \\
\text { rat } 20,000 \mu \mathrm{g} / \mathrm{g} \text { per } 4 \mathrm{~h}\end{array}$ & & & + & & & + & + & & & & & & + & & & & + & + & + \\
\hline 1-Propanol & TWA $200 \mu \mathrm{g} / \mathrm{g}\left(500 \mathrm{mg} / \mathrm{m}^{3}\right)$ & $\begin{array}{l}\text { Inhalation in rat } 20,000 \\
\mu \mathrm{g} / \mathrm{g} \text { per } 1 \mathrm{~h}\end{array}$ & & & & + & & & & & & & & & & & & & & & \\
\hline Propylene glycol & ND & ND & & & & + & & & & + & & + & + & & + & & & & & + & + \\
\hline Aldehyde & ND & ND & & & & & & & & & & & & & & & & & & & \\
\hline Acetaldehyde & TWA $200 \mu \mathrm{g} / \mathrm{g}\left(360 \mathrm{mg} / \mathrm{m}^{3}\right)$ & $\begin{array}{l}\text { Inhalation in rat } 13,300 \\
\mu \mathrm{g} / \mathrm{g} \text { per } 4 \mathrm{~h}\end{array}$ & & + & + & & & & & & & & & & & + & & + & & + & + \\
\hline Benzaldehyde & ND & ND & & + & & & & & & & & & & & & & & & & & \\
\hline \multirow{2}{*}{\multicolumn{22}{|c|}{ Ester }} \\
\hline & & & & & & & & & & & & & & & & & & & & & \\
\hline Butyl acetate & TWA $150 \mu \mathrm{g} / \mathrm{g}\left(710 \mathrm{mg} / \mathrm{m}^{3}\right)$ & $\begin{array}{l}\text { Inhalation in rat } 9.6 \text { to } \\
29.2 \mathrm{mg} / \mathrm{L} \text { per } 4 \mathrm{~h}\end{array}$ & & & & & & & & & & & & & & & & + & + & & + \\
\hline Butyl butyrate & ND & ND & & & & & & & & & & & & & & + & & + & & & \\
\hline Butyl butyryl lactate & ND & ND & & & & & & & & & & & & & & & + & & + & & \\
\hline Ethyl acetate & $\begin{array}{l}\text { TWA } 400 \mu \mathrm{g} / \mathrm{g} \\
\left(1,400 \mathrm{mg} / \mathrm{m}^{3}\right)\end{array}$ & $\begin{array}{l}\text { Inhalation in mouse } \\
45,000 \mathrm{mg} / \mathrm{m}^{3} \text { per } 4 \mathrm{~h}\end{array}$ & & & + & & & + & + & & & & & & + & & & & + & + & + \\
\hline Ethyl butyrate & ND & ND & & & & & & & & & & & & & + & & & & & + & + \\
\hline Ethyl octanoate & ND & ND & & & & & & & & & & & & & + & & + & & + & & \\
\hline Ethyl propionate & ND & ND & & & & & & & & & & & & & & & & & + & & \\
\hline \multicolumn{22}{|l|}{ Furans } \\
\hline Furan & ND & $\begin{array}{l}\text { Inhalation in rat } \\
3,398 \mu \mathrm{g} / \mathrm{g} \text { per } 1 \mathrm{~h}\end{array}$ & & & & + & & & & & & & & & & & & & & & \\
\hline Furfural & $\begin{array}{l}\text { TWA } 5 \mu \mathrm{g} / \mathrm{g}(20 \\
\left.\mathrm{mg} / \mathrm{m}^{3}\right)[\text { skin] }\end{array}$ & $\begin{array}{l}\text { Inhalation in } \\
\text { rat } 175 \mu \mathrm{g} / \mathrm{g} \text { per } 6 \mathrm{~h}\end{array}$ & & + & & & & & & & & & & & & & & & & & \\
\hline $\begin{array}{l}\text { 2-Furoic acid } \\
\text { Ketone }\end{array}$ & ND & \multicolumn{19}{|c|}{ Ketone } & \\
\hline Acetoin & $\mathrm{ND}$ & ND & & + & & & & & & + & + & & + & & + & + & + & & & + & + \\
\hline Acetone & $\begin{array}{l}\text { TWA } 1,000 \mu \mathrm{g} / \mathrm{g} \\
\left(2,400 \mathrm{mg} / \mathrm{m}^{3}\right)\end{array}$ & $\begin{array}{l}\text { Inhalation in rat } 50,100 \\
\mathrm{mg} / \mathrm{m}^{3} \text { per } 8 \mathrm{~h}\end{array}$ & & + & & + & + & + & + & & & & & & & & & & & & \\
\hline Diacetyl & ND & $\mathrm{ND}$ & + & + & + & + & + & + & + & + & $+t$ & + & + & + & + & + & + & & + & + & + \\
\hline 2-Butanone & TWA $200 \mu \mathrm{g} / \mathrm{g}\left(590 \mathrm{mg} / \mathrm{m}^{3}\right)$ & $\begin{array}{l}\text { Inhalation in mouse } \\
32,000 \mathrm{mg} / \mathrm{m}^{3} \text { per } 4 \mathrm{~h}\end{array}$ & & & & & & & & & & & & & & & & & & & + \\
\hline 2,3-Heptanedione & ND & ND & & & & & & & & & & & & & & & & & + & & \\
\hline
\end{tabular}




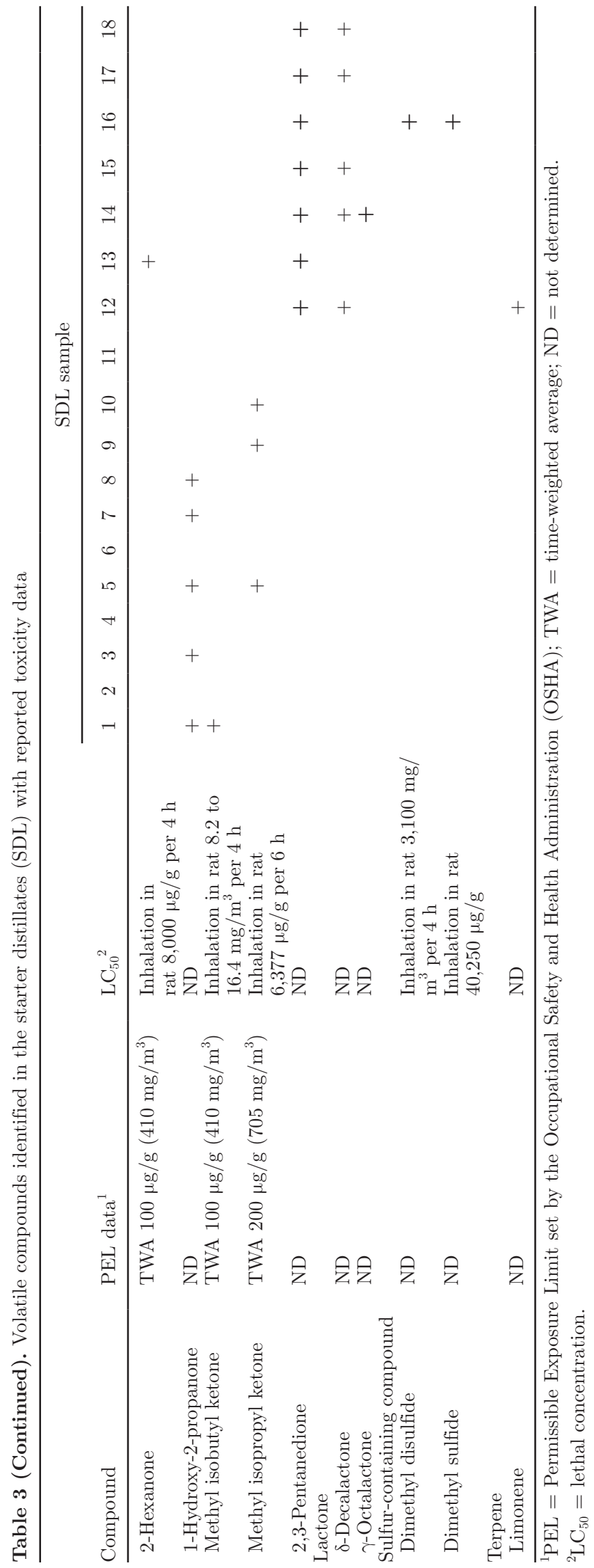

of 0.4 to $3.0 \mu \mathrm{g} / \mathrm{g}$ (Table 4 and Table 5). A synthetic flavored cultured butter formulated by Lindsay et al. (1967) suggests that an acetaldehyde concentration of $0.2 \mu \mathrm{g} / \mathrm{g}$, with a diacetyl content of 0.5 to $2.0 \mu \mathrm{g} / \mathrm{g}$ is desirable. In the specification sheet for SDL8, the manufacturer declared the addition of vanillin, which was confirmed in this study. Vanillin was also detected in SDL12, although not declared in the specification literature.

Among FEMA-designated high-priority flavoring chemicals, acetaldehyde has been linked to severe respiratory illness (Lockey et al., 2002) but its causative role remains unclear. The Occupational Safety and Health Administration permissible exposure limit (PEL) and lethal concentration $\left(\mathrm{LC}_{50}\right)$ for acetaldehyde are shown in Table 3. Acetaldehyde, which imparts green apple, nutty, and roasted flavor notes to foods, has considerable importance in the flavor of dairy products such as yogurt (Tamine and Deeth, 1980), cultured milks, and fresh cheeses (Urbach, 1995). Acetaldehyde is a fermentation byproduct produced by LAB from glucose via pyruvate and the so-called Entner-Doudoroff pathway (Armstrong and Brown, 1994).

A total of 7 esters were identified (Table 3). Ethyl acetate was identified in 7 SDL samples. Butyl acetate, ethyl butyrate, and ethyl octanoate were found in 3 different SDL samples, followed by butyl butyrate and butyl butyryl lactate in 2 different SDL samples. Ethyl propionate, a unique ester found in Swiss-type cheeses, was detected in SDL16. The presence of esters in the samples was consistently detected in non-diacetyl-based flavorants, with the exception of ethyl acetate found in 3 diacetyl-containing SDL (Table 3).

A mixture of ethyl acetate, ethyl propionate, ethyl octanoate, butyl acetate, and butyl butyrate constituted the $10 \%$ of the total peak areas in SDL16. In the same sample, 2,3-pentanedione was the major volatile representing the $85 \%$ of the total peak area. Additionally, SDL16 was the only sample that contained the sulfur-containing compounds, dimethyl sulfide and dimethyl disulfide. The manufacturer's literature states that SDL16 has butter, green, creamy, sulfur, mild, diacetyl-like notes and is intended for non-dairy applications such as cheese and sour cream analogs, margarines, and popcorn. Esters are produced via fermentation by microorganisms including bacteria such as LAB, molds, and yeasts. Ester synthesis is achieved through esterification and alcoholysis reactions of shortto medium-chain fatty acids and alcohols catalyzed by esterases, lipases, and alcohol acyltransferases (Liu et al., 2004). Esters are common components found in milk and fermented dairy products imparting fruity flavors described as apple-like, banana-like, pear-like, 
Table 4. Average concentrations ( $\mu \mathrm{g} / \mathrm{g}$ ) of Flavor and Extract Manufacturers Association (FEMA)-designated high-priority flavoring chemicals in diacetyl-based starter distillates (SDL)

\begin{tabular}{|c|c|c|c|c|c|c|c|c|c|}
\hline \multirow[b]{2}{*}{ Sample } & \multicolumn{9}{|c|}{ Concentration (SD) } \\
\hline & Acetaldehyde & $\begin{array}{l}\text { Acetic } \\
\text { acid }\end{array}$ & Acetoin & Benzaldehyde & $\begin{array}{c}\text { Butyric } \\
\text { acid }\end{array}$ & Diacetyl & $\begin{array}{l}\text { Formic } \\
\text { acid }\end{array}$ & Furfural & $\begin{array}{l}\text { Propanoic } \\
\text { acid }\end{array}$ \\
\hline SDL2 & $67(0.5)$ & $60,000(300)$ & $130,000(1,300)$ & $30(4.5)$ & & $16,000(2,800)$ & $13,000(1,000)$ & $0.3(0.0)$ & \\
\hline SDL3 & $18(3.0)$ & $170,000(8,100)$ & & & & $10,000(1,000)$ & & & $3,700(180)$ \\
\hline SDL4 & & $120,000(4,600)$ & & & & $13,000(1,700)$ & & & $690(41)$ \\
\hline SDL7 & & $200,000(2,300)$ & & & & $14,000(970)$ & & & $4,100(230)$ \\
\hline SDL8 & & $170,000(3,200)$ & $820(140)$ & & $2,300(220)$ & $3,400(440)$ & & & $420(20)$ \\
\hline SDL9 & & $63,000(2,400)$ & & & & $3,300(550)$ & $40,000(6,600)$ & & \\
\hline SDL10 & & $110,000(680)$ & & & $6,000(900)$ & $4,500(900)$ & & & $320(1.8)$ \\
\hline SDL11 & & $74,000(1,600)$ & & & & $100(16)$ & & & \\
\hline
\end{tabular}

${ }^{1}$ Mean values of triplicate measurements.

pineapple-like, ethereal, sweet, fermented, and yeasty (Margalith, 1981; Liu et al., 2004).

A total of 3 furans were found in the 18 SDL samples (Table 3). Of these, 2-furoic acid was the most abundant and positively detected in 6 samples (SDL1, SDL2, SDL3, SDL5, SDL6, and SDL8); furfural and furan were detected in SDL2 and SDL4, respectively. Furan may be generated from decarboxylation, cyclization, and dehydration of ascorbic acid or from lipid oxidation (Perez Locas and Yaylayan, 2004), but it is also associated with Maillard reactions between reducing sugars and amino acids such as lactose and casein (Blank, 2009). Both 2-furoic acid and furfural are precursors of furan (Limacher et al., 2007). When 2 -furoic acid is decarboxylated to produce furan, the latter undergoes an electrophilic aromatic substitution to yield furan (Becalski and Seaman, 2005). The International Agency for Research on Cancer (1995) has classified furan as a possible human carcinogen, with food consumption as the primary route of exposure. Likewise, the European Food Safety Authority (EFSA) linked furan as a potentially toxic compound in rats and mice administrated in a dose range of 100 to 200 $\mu \mathrm{g} / \mathrm{g}$ (NTP, 1993) with its carcinogenicity attributable to a genotoxic mechanism (EFSA, 2004).

Ten ketones were identified (Table 3). Diacetyl was positively identified in 17 samples and represents the most abundant compound in this group, followed by acetoin found in 8 and 2,3-pentanedione in 7 different SDL samples. Acetone and 1-hydroxy-2-propanone were detected in 5 samples and methyl isopropyl ketone in 3 SDL samples. The remaining ketones (2,3-heptanedione and methyl isobutyl ketone) and 2 methyl ketones (2-hexanone and 2-butanone) were each detected once in different SDL samples. Diacetyl and acetoin are common compounds produced by LAB metabolism of citrate (Cogan, 1995). Heterofermentative (Leuconostoc spp., especially Leuconostoc cremoris) and homofermentative bacteria (Strep. lactis ssp. diacetylactis) have been reported as starter cultures in several industrial processes for diacetyl production (Margalith, 1981). Diacetyl is reduced to acetoin and subsequently to 2,3-butanediol by diacetyl- and acetoin-dehydrogenases (Cadwallader and Singh, 2009). Butter flavorants containing diacetyl

Table 5. Average concentrations of Flavor and Extract Manufacturers Association (FEMA)-designated high-priority flavoring chemicals and diacetyl substitutes found in non-diacetyl based starter distillates (SDL)

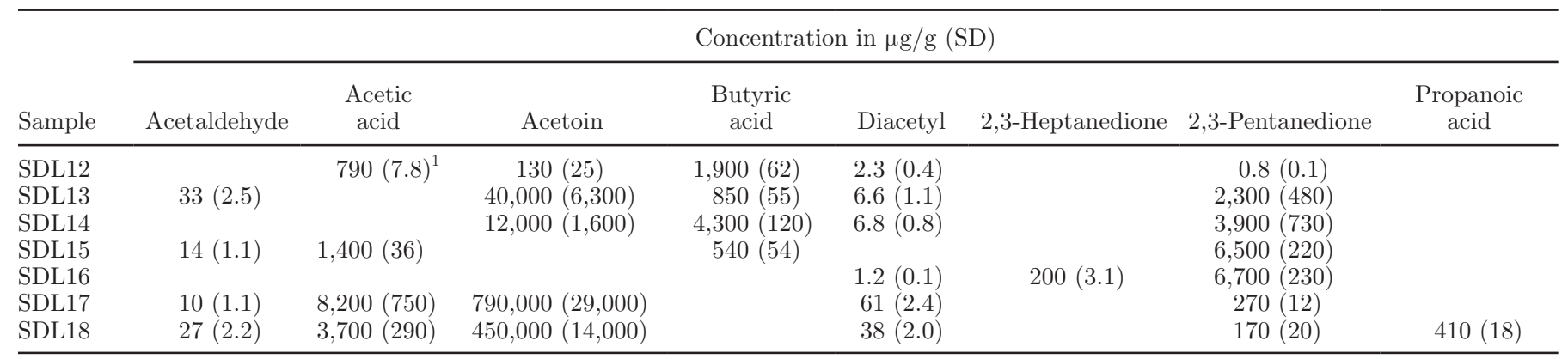

${ }^{1}$ Mean values of triplicate measurements. 
are combined with butyric acid, which inhibits diacetyl dehydrogenase and acetoin production (Nakagawa et al., 2002). Diacetyl was detected in all SDL samples excluding SDL15, a non-diacetyl flavorant. The SDL1, SDL4, SDL8, and SDL10 manufacturers reported the addition of natural diacetyl as an ingredient.

In non-diacetyl-based flavorants, diacetyl was detected in a range of 1.2 to $61 \mu \mathrm{g} / \mathrm{g}$ (Table 5). In SDL12, butyric acid, acetoin, acetic acid, butyl butyrate, vanillin, and $\delta$-decalactone were the predominant (largest peak areas) volatile components. Acetoin, 2,3-pentanedione, and butyric acid were the predominant volatiles present in SDL13. In SDL14, acetoin, 2,3-pentanedione, butyric acid, butyl butyryl lactate, and $\delta$-decalactone were predominant. The compound 2,3-pentanedione was detected in the largest amount in SDL15 and SDL16 (Table 5). Likewise, butyric acid and butyl acetate were major volatile components in SDL15; butyl acetate, ethyl propionate, and sulfur-containing compounds were major volatile components in SDL16. Acetoin was present as a major component in SDL17 and SDL18.

Two methyl ketones were identified in SDL (Table 3). 2-Butanone and 2-hexanone were detected in 2 nondiacetyl-based flavorants, with the latter at the highest relative concentration. Methyl ketones may be formed through several means, including the oxidation of hydroxy fatty acids. Methyl ketones are flavor volatiles associated with blue-veined cheeses (Gripon et al., 1991).

In this work, 2 lactones were exclusively detected in non-diacetyl-based flavorants (Table 3 ). $\delta$-Decalactone was the most abundant and positively identified in 5 samples. $\delta$-Decalactone is considered a potent dairy flavor compound in butter and buttermilk (McGorrin, 2001) and generally used in combination with FFA and methyl ketones to produce creamy fatty notes in commercial flavorants. $\gamma$-Octalactone was only found in 1 sample (SDL14). Such lactones result from fatty acid hydroxylation to produce the corresponding hydroxy acids, which spontaneously cyclize to $\delta$ or $\gamma$ lactones (McGorrin, 2001).

Dimethyl sulfide and dimethyl disulfide were detected only in the non-diacetyl-based SDL16 (Table 3), representing $4.54 \%$ of the total peak area. Catabolism of sulfur-containing amino acids can result in several important sulfur flavor compounds. For example, in the presence of oxygen, methanethiol reacts with itself, producing dimethyl sulfide. The catabolic products, including methanethiol, dimethyl sulfide and dimethyl disulfide, play an important role in the aroma of fermented products (Margetts, 2009). Dimethyl sulfide, which has a green radish or cabbage odor, is derived from methionine. Its relative concentration in SDL16 is over 15 times lower than dimethyl disulfide. Dimethyl disulfide, with a sulfur and cabbage odor, may be de- rived from several metabolic or spontaneous pathways including Strecker degradation. These compounds have been associated as an important contributor in milk aroma (Moio et al., 1994), yogurt (Imhof et al., 1995), and Cheddar (Aston and Dulley, 1982), Parmesan (Barbieri et al., 1994), and Swiss (Bosset and Liardon, 1985) cheeses.

Limonene was exclusively identified in SDL12 (Table $3)$. This terpene, which has a citrus aroma note, has been found in dairy products, including Cheddar cheese (Singh et al., 2004), and may originate from a grazing feed source (Mariaca et al., 1997; Urbach, 1997).

\section{Quantitative Analysis of Selected SDL Compounds}

From a list of several thousand flavoring substances, the FEMA has listed 83 that may present respiratory hazards. Of these, 34 have been described as high priority and 48 as low priority substances relative to their respiratory toxicity. These classifications are based on the availability of inhalation exposure data in animals and humans, chemical structure, and the volatility of each compound (FEMA, 2004). The high priority substances may have sufficient volatility and potential reactivity to cause a respiratory injury in certain conditions related to exposure time, exposure levels, processing parameters such as temperature and airflow, and safety measures. Of the compounds found in SDL, acetaldehyde, acetic acid, acetoin, benzaldehyde, butyric acid, diacetyl, formic acid, furfural, and propanoic acid are regarded as high priority substances (Table 4). Table 5 shows the FEMA-designated high-priority flavoring chemicals and diacetyl substitutes compounds found in non-diacetyl-based flavorants (acetaldehyde, acetic acid, acetoin, butyric acid, diacetyl, 2,3-heptanedione, 2,3-pentanedione, and propanoic acid).

For discussion purposes diacetyl-based flavorants (SDL1-SDL11) were divided in 4 groups according to diacetyl concentrations as reported by the manufacturers $(1 \times, 5 \times, 15 \times$, and $30 \times)$. Diacetyl, acetic acid, and propanoic acid (listed as FEMA-designated high-priority flavoring chemicals) concentrations were determined in SDL1, the single $30 \times$ sample. Acetic acid was the most abundant volatile $(290,000 \mu \mathrm{g} / \mathrm{g})$, followed by diacetyl $(22,000 \mu \mathrm{g} / \mathrm{g})$, and propanoic acid $(22,000 \mu \mathrm{g} / \mathrm{g}$; Table 4). High levels of acetic acid and propionic acid were expected due to the intended uses recommended by the manufacturer providing sharp, sour, or vinegar notes in salad dressing applications.

Within the $15 \times$ group of SDL (SDL2-SDL7), the FEMA-designated high-priority flavoring compounds included acetaldehyde, acetic acid, acetoin, diacetyl, formic acid, furfural, propanoic acid, and benzaldehyde (Table 4). Acetic acid and diacetyl were present in all 
Table 6. Average concentrations ${ }^{1}$ of Flavor and Extract Manufacturers Association (FEMA) high-priority compounds and diacetyl substitutes found in selected dairy products

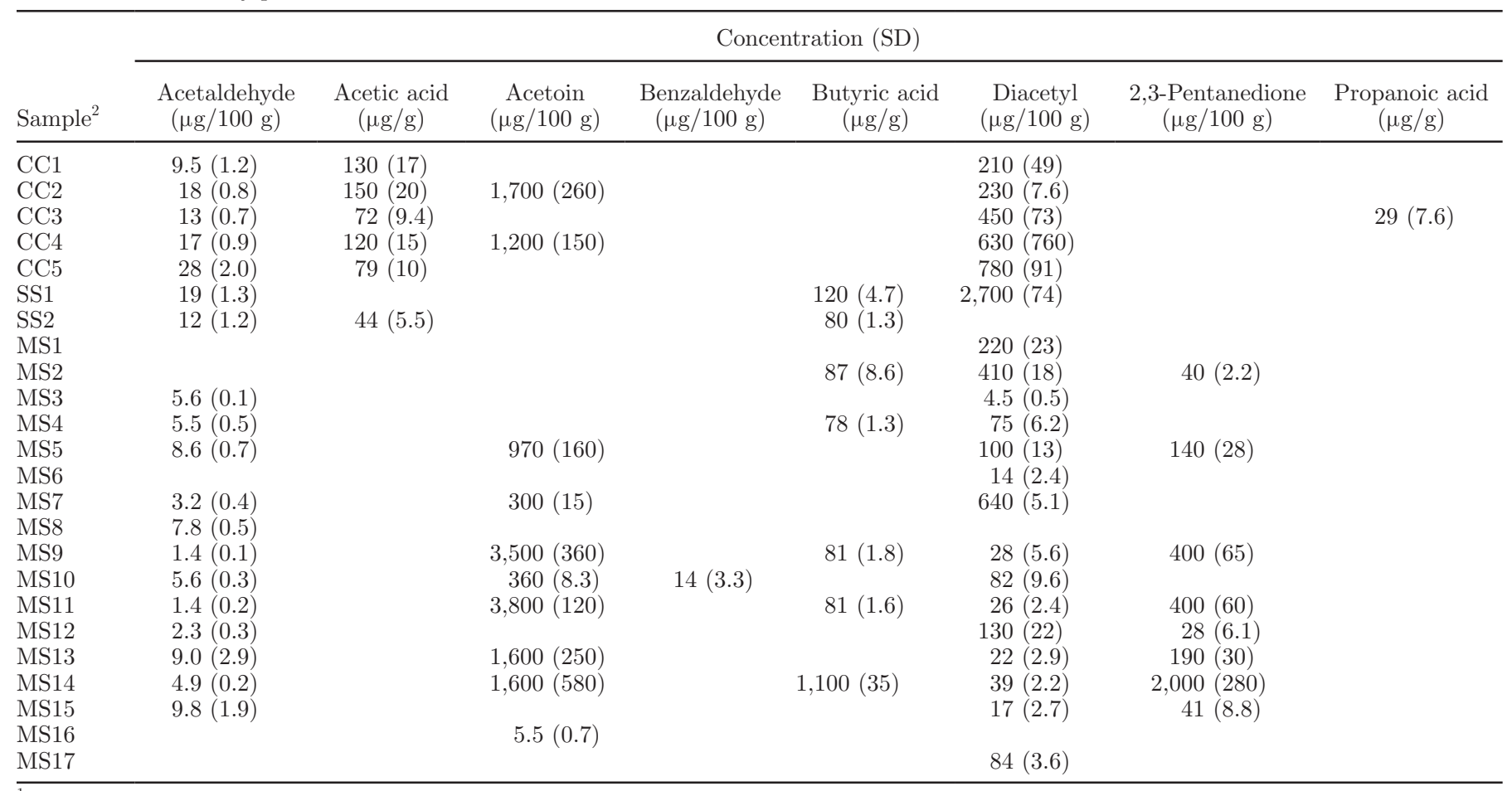

${ }^{1}$ Mean values of triplicate measurements

${ }^{2} \mathrm{CC}=$ cottage cheese; $\mathrm{SS}=$ spread in spray form; MS = margarine or vegetable oil spread.

samples ranging from 53,000 to $200,000 \mu \mathrm{g} / \mathrm{g}$ and 8,300 to $16,000 \mu \mathrm{g} / \mathrm{g}$, respectively.

Acetoin was identified in SDL2 and SDL6 $(130,000$ and $8,000 \mu \mathrm{g} / \mathrm{g}$ ) and propanoic acid in all samples (690-4,100 $\mu \mathrm{g} / \mathrm{g})$ except in SDL2 and SDL5 where formic acid was found $(13,000$ and $50,000 \mu \mathrm{g} / \mathrm{g}$, respectively). Acetaldehyde was detected in SDL2 and SDL3 (67 and $18 \mu \mathrm{g} / \mathrm{g}$ respectively), whereas benzaldehyde $(30 \mu \mathrm{g} / \mathrm{g})$ and furfural $(0.3 \mu \mathrm{g} / \mathrm{g})$ were solely identified in SDL2.

In the third group of SDL $(5 \times)$, including SDL8, SDL9, and SDL10, diacetyl concentrations ranged from 3,300 to $4,500 \mu \mathrm{g} / \mathrm{g}$. Besides diacetyl, other FEMAdesignated high-priority compounds were found; SDL9, declared as a butter flavorant with lactic acid notes, contained acetic acid $(63,000 \mu \mathrm{g} / \mathrm{g})$ and formic acid $(40,000 \mu \mathrm{g} / \mathrm{g})$; SDL8 and SDL10, described as buttermilk-type flavors, contained acetic acid $(170,000$ and $110,000 \mu \mathrm{g} / \mathrm{g})$, butyric acid $(2,300$ and $6,000 \mu \mathrm{g} / \mathrm{g})$, and propanoic acid (420 and $320 \mu \mathrm{g} / \mathrm{g}$ ), respectively. Diacetyl $(100 \mu \mathrm{g} / \mathrm{g})$ and acetic acid $(74,000 \mu \mathrm{g} / \mathrm{g})$ were quantified in SDL11 $(1 \times)$.

Concentrations of acetaldehyde, acetic acid, acetoin, butyric acid, diacetyl, and propanoic acid found in non-diacetyl-based flavorants (SDL12-SDL18) were de- termined (Table 5). In addition, quantitative analysis for diacetyl substitutes, including 2,3-pentanedione and 2,3-hexanedione, was performed (Table 5).

Major quantitative differences were found in diacetyl, acetoin, and acetic acid concentrations (Table 5). Diacetyl was detected in all samples excluding SDL15 at a range of 1.2 to $61 \mu \mathrm{g} / \mathrm{g}$. Acetoin was found in all non-diacetyl-based flavorants excluding SDL15 and SDL16 (Table 5). Acetoin levels were relatively higher in SDL17 and SDL18, reaching 790,000 and 450,000 $\mu \mathrm{g} / \mathrm{g}$, representing approximately 80 and $45 \%$ of the flavorant, respectively. Acetic acid concentrations in SDL12, SDL15, DS17, and SDL18 ranged from 790 to $8,200 \mu \mathrm{g} / \mathrm{g}$. Acetaldehyde (ranging from 10 to $33 \mu \mathrm{g} / \mathrm{g}$ ) and butyric acid (ranging from 540 to $4,300 \mu \mathrm{g} / \mathrm{g}$ ) concentrations were comparable to diacetyl-based flavorant levels. Propanoic acid was exclusively found in SDL18 with a concentration of $410 \mu \mathrm{g} / \mathrm{g}$.

Alternative compounds for diacetyl were quantified, namely 2,3-pentanedione and 2,3-hexanedione (Table 5). 2,3-Pentanedione was detected in all samples ranging from 0.8 to $6,700 \mu \mathrm{g} / \mathrm{g} ;$ SDL15 and SDL16 contained the highest concentrations (Table 5). 2,3-Heptanedione found solely in SDL16 was detected in a concentration of $200 \mu \mathrm{g} / \mathrm{g}$. 


\section{Quantitative Analysis of Selected Dairy Product Cottage Cheeses}

The CFR defines cottage cheese as a "soft uncured cheese prepared by mixing cottage cheese dry curd with a creaming mixture" (CFR, 2011b). The finished food contains no more than $80 \%$ moisture and not less than $4 \%$ milkfat by weight (CFR, 2011b). According to Clark and Potter (2007), a high-quality product should possess a slightly acidic flavor with a buttery flavor note and a creamy aroma. Diacetyl is recognized as a key flavor contributor to cottage cheese (Leksrisompong et al., 2010) and identified as a critical in consumer preferences (Drake et al., 2009). High diacetyl levels are associated with a flavor imbalance, bitter taste, and harsh aroma (Clark and Potter, 2007). The aroma threshold of diacetyl in full-fat cottage cheese has been reported to be $0.2 \mu \mathrm{g} / \mathrm{g}$ (Antinone et al., 1994; Drake et al., 2009) and diacetyl concentrations in cottage cheeses below $0.62 \mu \mathrm{g} / \mathrm{g}$ are considered to have a flat aroma (Parker and Elliker, 1953).

A total of 5 FEMA-designated high-priority flavoring constituents (acetaldehyde, acetic acid, acetoin, diacetyl, and propanoic acid) were found in the 5 commercial cottage cheeses (Table 6). Diacetyl ranged from 210 to $780 \mu \mathrm{g} / 100 \mathrm{~g}$. In the fat-free sample (CC5), the diacetyl level was $780 \mu \mathrm{g} / 100 \mathrm{~g}$, whereas in lowfat cheeses (CC3 and CC4), diacetyl concentrations were 450 and 630 $\mu \mathrm{g} / 100 \mathrm{~g}$. Lower diacetyl concentrations were found in full-fat samples (4\% milkfat) at 210 and $230 \mu \mathrm{g} / \mathrm{g}$. According to Antinone et al. (1994), consumers prefer higher concentrations of diacetyl in low-fat cottage cheeses $(400 \mu \mathrm{g} / 100 \mathrm{~g})$ compared with full-fat cottage cheese, where mean aroma rating increased with higher diacetyl concentrations.

Besides diacetyl, acetic acid $(72-150 \mu \mathrm{g} / \mathrm{g})$ and acetaldehyde $(9.5-28 \mu \mathrm{g} / 100 \mathrm{~g})$ were found in all samples. Acetic acid was found at higher concentrations compared with the other high-priority components. According to White and White (1999), for a desirable cottage cheese flavor, acetaldehyde levels should be lower than diacetyl, whereas in yogurt flavor, the opposite is preferred. Acetoin was present in CC2 and CC4 (1,700 and $1,200 \mu \mathrm{g} / 100 \mathrm{~g}$, respectively). Propanoic acid was solely found in CC3 with a concentration of $29 \mu \mathrm{g} / \mathrm{g}$.

\section{Margarine and Spreads}

In the past, cultured milk was used as a flavor source in the production of margarines and spreads. For improvements in cost, consistency, and manufacturing time, cultured milk may replaced by skim milk with added SDL or pure diacetyl and other flavor components. Diacetyl concentrations in butter have been reported to range from 1 to $4 \mu \mathrm{g} / \mathrm{g}$ (Chrysan, 2005). A total of 19 commercial margarines and vegetable oil spreads were evaluated and 7 FEMA-designated highpriority flavoring compounds (acetaldehyde, acetic acid, acetoin, benzaldehyde, butyric acid, diacetyl, and 2,3-pentanedione) were found and quantified (Table 6). Diacetyl was detected in 16 samples in a range of 4.5 to $2,700 \mu \mathrm{g} / 100 \mathrm{~g}$. The highest levels of diacetyl were found in samples with higher fat content, such as a $56 \%$ vegetable oil spread in spray presentation (SS1), followed by MS7 (65\% vegetable oil spread), and 2 margarine samples MS1 and MS2 with $80 \%$ fat.

Acetaldehyde was found in 14 vegetable oil spread samples but not detected in margarine samples (MS1 and MS2). Acetaldehyde concentration ranged from 1.4 to $9.8 \mu \mathrm{g} / 100 \mathrm{~g}$. Acetoin (5.5 to $1,600 \mu \mathrm{g} / 100 \mathrm{~g}$ ) and 2,3-pentanedione (41 to $2,000 \mu \mathrm{g} / 100 \mathrm{~g}$ ) were detected in 8 different samples. The highest concentrations of these volatile compounds were found among reduced- and low-fat content samples (60\% fat content or below), especially in MS9, MS11, MS13 and MS14. Butyric acid, identified in 7 samples, ranged from 80 to $1,100 \mu \mathrm{g} / \mathrm{g}$ whereas acetic acid was identified solely in SS2, a $44 \%$ vegetable oil spread in spray presentation. Finally, benzaldehyde $(14 \mu \mathrm{g} / 100 \mathrm{~g})$ was found exclusively in a $53 \%$ vegetable oil spread containing natural and artificial flavors (MS10).

\section{CONCLUSIONS}

This work provides a baseline qualitative and quantitative characterization of diacetyl and related compounds in a common GRAS additive, SDL, and some foods that contain SDL. Although toxicity is a complex phenomenon, this information is intended to provide manufacturers with additional information on which to base formulation and handling practices. Additional work may involve the reactivity and fate of these compounds during processing and storage as well as their interaction with chemicals designed for cleaning and sanitizing of dairy processing equipment.

\section{REFERENCES}

Antinone, M. J., H. T. Lawless, R. A. Ledford, and M. Johnston. 1994. Diacetyl as a flavor component in full-fat cottage cheese. J. Food Sci. 59:38-42

Armstrong, D. W., and L. A. Brown. 1994. Aliphatic, aromatic, and lactone compounds. Pages 41-89 in Bioprocess Production of Flavor, Fragrance, and Color Ingredients. A. Gabelman, ed. John Wiley \& Sons Inc., New York, NY.

Aston, J. W., and J. R. Dulley. 1982. Cheddar cheese flavor. Aust. J. Dairy Technol. 37:59-64.

Barbieri, G., L. Bolzoni, M. Careri, A. Mangia, G. Parolari, S. Spagnoli, and R. Virgili. 1994. Study of the volatile fraction of Parmesan cheese. J. Agric. Food Chem. 42:1170-1176.

Bartowsky, E. J., and P. A. Henschke. 2004. The 'buttery' attribute of wine-diacetyl-desirability, spoilage and beyond. Int. J. Food Microbiol. 96:235-252. 
Becalski, A., and S. Seaman. 2005. Furan precursors in food: A model study and development of a simple headspace method for determination of furan. J. AOAC Int. 88:102-106.

Blank, I. 2009. Furan in Processed Foods. Pages 291-322 in Bioactive Compounds in Food. J. Gilbert and H. Z. Şenyuva, ed. Blackwell Publishing Ltd., Oxford, UK.

Bosset, J. O., and R. Liardon. 1985. The aroma composition of Swiss Gruyère. III. Relative changes in the content of alkaline and neutral volatile components during ripening. Lebensm. Wiss. Technol. 18:178-185.

Cadwallader, K. R., and T. K. Singh. 2009. Flavours and off-flavours in milk and dairy products. Pages 631-690 in Advanced Dairy Chemistry. Vol. 3, Lactose, Water, Salts and Minor Constituents. 3rd ed. P. L. H. McSweeney and P. F. Fox, ed. Springer-Verlag, New York, NY.

CFR. 2011a. Starter distillate (21CFR184.1848). Page 546 in Code of Federal Regulations, Title 21, Vol. 3. US Government Printing Office, Washington, DC.

CFR. 2011b. Dry curd cottage cheese (21CFR133.129). Page 320-321 in Code of Federal Regulations, Title 21, Vol. 2. US Government Printing Office, Washington, DC.

Chan, A., and R. Allen. 2004. Bronchiolitis obliterans: An update. Curr. Opin. Pulm. Med. 10:133-141.

Chrysan, M. M. 2005. Margarines and spreads. Pages 32-82 in Bailey's Industrial Oil and Fat Products, Vol 4. A. Bailey and F. Shahidi, ed. John Wiley \& Sons, Hoboken, NJ.

Chuang, L. F., and E. B. Collins. 1968. Biosynthesis of diacetyl in bacteria and yeast. J. Bacteriol. 95:2083-2089.

Clark, S., and E. D. Potter. 2007. Cottage Cheese. Pages 618-633 in Handbook of Food Products Manufacturing: Health, Meat, Milk, Poultry, Seafood and Vegetables. Vol. 2. Y. H. Hui, ed. John Wiley \& Sons Inc., Hoboken, NJ.

Cogan, T. M. 1995. Flavour production by dairy starter cultures. J. Appl. Bacteriol. 79:49S-64S.

Drake, S. L., K. Lopetcharat, and M. A. Drake. 2009. Comparison of two methods to explore consumer preferences for cottage cheese. J. Dairy Sci. 92:5883-5897.

EFSA (European Food Safety Authority). 2004. Report of the scientific panel on contaminants in the food chain on provisional findings of furan in food. European Food Safety Authority, Parma, It.

Ezrailson, E. G. 2002. Bronchiolitis in popcorn-factory workers. N Engl. J. Med. 347:1980-1982

FEMA (Flavor and Extract Manufacturers Association). 2004. Respiratory Health and Safety in the Flavor Manufacturing Workplace. The Flavor and Extract Manufacturers Association of the United States, Washington, DC

Gripon, J.-C., V. Monnet, G. Lambert, and M. J. Desmazeaud. 1991. Microbial enzymes in cheese ripening. Pages 131-168 in Food Enzymology. Vol. 1. P. F. Fox, ed. Elsevier Applied Science Publishers, London, UK

Hayasaka, Y., and E. J. Bartowsky. 1999. Analysis of diacetyl in wine using solid-phase microextraction combined with gas chromatography mass spectrometry. J. Agric. Food Chem. 47:612-617.

Hempenius, W. L., B. J. Liska, and R. B. Harrington. 1965. Consumer preferences for flavor in creamed cottage cheese. J. Dairy Sci. 48:870.

Hubbs, A. F., A. E. Moseley, W. T. Goldsmith, M. C. Jackson, M. L. Kashon, L. A. Battelli, D. Schwegler-Berry, M. P. Goravanahally, D. Frazer, J. S. Fedan, K. Kreiss, and V. Castranova. 2010. Airway epithelial toxicity of the flavoring agent, 2,3-pentanedione. The Toxicologist CD 114:319. (Abstr.)

International Agency for Research on Cancer (IARC). 1995. Furan. Pages 393-407 in IARC Monographs on the Evaluation of Carcinogenic Risks to Humans: Dry Cleaning, Some Chlorinated Solvents and Other Industrial Chemicals. Vol. 63. IARC, Lyon, France.

Imhof, R., H. Glättli, and J. O. Bosset. 1995. Volatile organic-compounds produced by thermophilic and mesophilic single strain dairy starter cultures. Lebenson. Wiss. Technol. 28:78-86.

Kanwal, R. 2008. Bronchiolitis obliterans in workers exposed to flavoring chemicals. Curr. Opin. Pulm. Med. 14:141-146.
Kreiss, K. 2007. Flavoring-related bronchiolitis obliterans. Curr. Opin. Allergy Clin. Immunol. 7:162-167.

Kullman, G., R. Boylstein, W. Jones, C. Piacitelli, S. Pendergrass, and K. Kreiss. 2005. Characterization of respiratory exposures at a microwave popcorn plant with cases of bronchiolitis obliterans. J. Occup. Environ. Hyg. 2:169-178.

Landaud, S., P. Lieben, and D. Picque. 1998. Quantitative analysis of diacetyl, pentanedione and their precursors during beer fermentation by an accurate GC/MS method. J. Inst. Brew. 104:93-99.

Leksrisompong, P., D. M. Barbano, A. E. Foegeding, P. Gerard, and M. Drake. 2010. The roles of fat and $\mathrm{pH}$ on the detection thresholds and partition coefficients of three compounds: Diacetyl, $\delta$-decalactone and furaneol. J. Sens. Stud. 25:347-370.

Limacher, A., J. Kerler, B. Conde-Petit, and I. Blank. 2007. Formation of furan and methylfuran from ascorbic acid in model systems and food. Food Addit. Contam. 24:122-135.

Lindsay, R. C., E. A. Day, and L. A. Sather. 1967. Preparation and evaluation of butter culture flavor concentrates. J. Dairy Sci. $50: 25-31$.

Liu, S.-Q., R. Holland, and V. L. Crow. 2004. Esters and their biosynthesis in fermented dairy products: A review. Int. Dairy J. 14:923-945.

Lockey, J., R. McKay, E. Barth, J. Dahlsten, and R. Baughman. 2002. Bronchiolitis obliterans in the food flavoring manufacturing industry. Am. J. Respir. Crit. Care Med. 165:461. (Abstr.)

Margalith, P. Z. 1981. Dairy products. Pages $32-118$ in Flavor Microbiology. P. Z. Margalith, ed. Charles C Thomas Publisher, Springfield, IL.

Margetts, J. 2009. Aroma chemicals V: Natural aroma chemicals. Pages 169-198 in Chemistry and Technology of Flavours and Fragrances. D. J. Rowe, ed. CRC Press LLC, Boca Raton, FL.

Mariaca, R. G., T. F. H. Berger, R. Gauch, M. I. Imhof, B. Jeangros, and J. O. Bosset. 1997. Occurrence of volatile mono- and sesquiterpenoids in highland and lowland plant species as possible precursors for flavor compounds in milk and dairy products. J. Agric. Food Chem. 45:4423-4434

McGorrin, R. J. 2001. Advances in dairy flavor chemistry. Pages 85-97 in Food Flavors and Chemistry: Advances of the New Millennium. A. M. Spanier, F. Shahidi, T. H. Parliment, T. Mussinan, C.-T. Ho, and E. T. Contis, ed. The Royal Society of Chemistry, Cambridge, UK.

Miedema, J. P., and E. Schildknecht. 2007. Flavourings for confectioneries, baked goods, ice-cream and dairy products. Pages 515-569 in Flavourings: Production, Composition, Applications, Regulations. 2nd ed. H. Ziegler, ed. Wiley-VCH, Aufseß, Germany.

Moio, L., P. Etievant, D. Langlois, J. Dekimpe, and F. Addeo. 1994. Detection of powerful odorants in heated milk by use of extract dilution sniffing analysis. J. Dairy Res. 61:385-394.

Monnet, C., P. Schmitt, and C. Divies. 1994. Diacetyl production in milk by an $\alpha$-acetolactic acid accumulating strain of Lactococcus lactis ssp. lactis biovar. diacetylactis. J. Dairy Sci. 77:2916-2924.

Nakagawa, J., S. Ishikura, J. Asami, T. Isaji, N. Usami, A. Hara T. Sakurai, K. Tsuritani, K. Oda, M. Takahashi, M. Yoshimoto, N. Otsuka, and K. Kitamura. 2002. Molecular characterization of mammalian dicarbonyl/L-xylulose reductase and its localization in kidney. J. Biol. Chem. 277:17883-17891.

NIOSH (National Institute for Occupational Safety and Health). 2010. Request for information on 2,3-pentanedione and other alphadiketones used as diacetyl substitutes. The National Institute for Occupational Safety and Health, Atlanta, GA.

NTP (National Toxicology Program). 1993. Toxicology and carcinogenesis studies of furan (CAS No. 110-00-9) in F344/N rats and B6C3Fl mice (gavage studies), NTP Technical Report No. 402, US Department of Health and Human Services, Public Health Service, National Institutes of Health, Research Triangle Park, NC

OSHA (Occupational Safety and Health Administration). 2010. Occupational exposure to flavoring substances: Health effects and hazard control. Safe and health Information Bulletin. Accessed Apr. 3, 2011. http://www.osha.gov/dts/shib/shib10142010.html. 
Parker, R. B., and P. R. Elliker. 1953. Effect of spoilage bacteria on biacetyl content and flavor of cottage cheese. J. Dairy Sci. 36:843-849.

Perez Locas, C., and V. A. Yaylayan. 2004. Origin and mechanistic pathways of formation of the parent furan-A food toxicant. J. Agric. Food Chem. 52:6830-6836.

Portno, A. D. 1966. Some factors affecting the concentration of diacetyl in beer. J. Inst. Brew. 72:193-196.

Singh, T., M. A. Drake, and K. R. Cadwallader. 2004. Flavor of Cheddar cheese: A chemical and sensory perspective. Compr. Rev. Food Sci. Food Saf. 2:139-162.

Tamine, A. Y., and H. C. Deeth. 1980. Yoghurt: Technology and biochemistry. J. Food Prot. 43:939-977.

Urbach, G. 1995. Contribution of lactic acid bacteria to flavour compound formation in dairy products. Int. Dairy J. 5:877-903.
Urbach, G. 1997. The flavour of milk and dairy products. II. Cheese: Contribution of volatile compounds. Int. J. Dairy Technol. 50:79 89 .

van Rooy, F. G. B. G. J., J. M. Rooyackers, M. Prokop, R. Houba, L. A. M. Smit, and D. J. J. Heederik. 2007. Bronchiolitis obliterans syndrome in chemical workers producing diacetyl for food flavorings. Am. J. Respir. Crit. Care Med. 176:498-504.

Veringa, H. A., E. H. Verburg, and J. Stadhouders. 1984. Determination of diacetyl in dairy-products containing $\alpha$-acetolactic acid Neth. Milk Dairy J. 38:251-263.

White, S., and G. White. 1999. The development of dairy flavoring. Pages 327-366 in Food Flavorings. 3rd ed. P. R. Ashurst, ed. Aspen Publishers Inc., Gaithersburg, MD. 